\title{
UJI AKTIVITAS ANTIOKSIDAN KOMBINASI INFUSA DAUN SIRIH (Piper Betle L), EKSTRAK ETANOLIK TANAMAN BUNDUNG (Actinuscirpus Grossus) DAN KULIT JERUK NIPIS (Citrus Aurantifolia)
}

\section{Antioxidant Activity Combination Of Piper Betle Leaf Infusion, Ethanolic Extract Of Bundung (Actinuscirpus Grossus) And Citrus Fruit Peel Of Citrus Aurantifolia}

\author{
Kunti Nastiti ' \\ Noval $^{2}$ \\ Darini Kurniawati ${ }^{3}$ \\ *IUniversitas Sari Mulia, \\ Banjamasin, Kalimantan Selatan, \\ Indonesia \\ 2 Universitas Sari Mulia, \\ Banjamasin, Kalimantan Selatan, \\ Indonesia \\ 3 Universitas Sari Mulia, \\ Banjamasin, Kalimantan Selatan, \\ Indonesia \\ *email: \\ kuntinastiti86@gmail.com
}

\section{Kata Kunci:}

Antibodi leguler

Identifikasi antibodi

Multitransfusi

Keywords:

Iregular antibody

Antibody Identification

Multitransfusion

\begin{abstract}
Abstrak
Daun sirih (piper betle $L$ ) merupakan tanaman yang paling sering digunakan untuk pengobatan dan telah terbukti secara ilmiah memiliki aktivitas sebagai antibakteri. Tanaman Bundung (actinuscirpus grossus) banyak ditemukan di Kalimantan dan berkhasiat sebagai antimikroba. Kulit Jeruk nipis (citrus aurantifolia) memiliki efek antioksidan dan kandungan senyawa kimia yang berkhasiat dalam pengobatan. Tujuan penelitian ini untuk mengetahui pengaruh aktivitas antioksidan kombinasi infusa daun sirih (piper betle l), ekstrak etanolik tanaman bundung (actinuscirpus grossus) dan kulit jeruk nipis (citrus aurantifolia). Metode penelitian adalah eksperimental dengan cara daun sirih dibuat infusa dengan pelarut air. Serbuk simplisia tanaman bundung dan Kulit jeruk nipis diekstraksi dengan cara maserasi dengan pelarut etanol $95 \%$. Kombinasi ketiga tanaman tersebut kemudian diuji antioksidan dengan metode DPPH. Quersetin digunakan sebagai kontrol positif. Hasil penelitian menunjukkan bahwa kombinasi ketiga tanaman tersebut memiliki aktivitas antioksidan sedang (IC50 I $28 \mu \mathrm{g} / \mathrm{mL}$ ), akan tetapi aktivitas antiokidan tersebut lebih kecil daripada quersetin (IC50 16,88 $\mu \mathrm{g} / \mathrm{mL}$ ). Kombinasi infusa daun sirih (piper betle I), ekstrak etanolik tanaman bundung (actinuscirpus grossus) dan kulit jeruk nipis (citrus aurantifolia) mempunyai kategori antioksidan sedang.
\end{abstract}

\begin{abstract}
Piper betle L., leaf is the plant most often used for treatment and has been scientifically proven to have antibacterial activity. Actinuscirpus grossus plant are commonly found in Kalimantan and have antimicrobial properties. Citrus aurantifolia peel has antioxidant effects and nutritious chemical compounds in medicine. The purpose of this study was to determine the effect of antioxidant activity in a combination of in Piper betle L., leaf infusion, ethanolic extract of Actinuscirpus grossus plant and Citrus aurantifolia peel. The research method was experimental by making Piper betle L., leaves infused with water solvent. Simplisia powder of Actinuscirpus grossus plants and Citrus aurantifolia peel extracted by maceration with 95\% ethanol solvent. The combination of the three plants was then tested for antioxidants by the DPPH method. Quersetin is used as a positive control. The results showed that the combination of the three plants had moderate antioxidant activity (IC 50 I $28 \mathrm{ppm}$ ), but the antioxidant activity was smaller than quersetin (IC 50 $16.88 \mathrm{ppm})$. The combination of Piper betle L., leaf infusion, ethanolic extract of Actinuscirpus grossus plant and Citrus aurantifolia peel has moderate antioxidant category.
\end{abstract}

(C) year The Authors. Published by Institute for Research and Community Services Universitas Muhammadiyah Palangkaraya. This is Open Access article under the CC-BY-SA License (http://creativecommons.org/licenses/by-sa/4.0/) DOI: https://doi.org//0.33084/jsm.vxix.xxx.

\section{PENDAHULUAN}

Sumber pembentuk senyawa radikal bebas berasal dari makanan yang digoreng, dibakar, paparan matahari yang berlebihan, racun dan polusi, asap rokok, obatobatan tertentu dan banyak ditemui dalam kehidupan sehari-hari (Pietta, 2000). Radikal bebas ini merupakan salah satu penyebab kerusakan dan kematian sel (Majewska et al., 20II). Atom atau molekul radikal bebas sangat tidak stabil dan reaktif. Orbital terluarnya tidak mempunyai pasangan elektron sehingga akan bereaksi dengan molekul di sekitarnya dan 
menimbulkan kerusakan sel maupun gangguan metabolisme. Senyawa antioksidan merupakan substansi yang dapat menangkal radikal bebas sehingga dapat mencegah kerusakan yang terjadi akibat radikal bebas (Winarsi, H., 2007).

Salah satu sumber antioksidan di bumi ini adalah berasal dari tanaman. Penelitian yang berkaitan dengan antioksidan terus menerus dikembangkan untuk mendapatkan antioksidan yang potensial bahkan sampai ke tahap formulasi untuk mendapatkan suatu produk farmasi (Haryono et al., 202I) yang bermanfaat di tengah masyarakat (Noval et al., 2020). Beberapa tanaman yang telah diuji aktivitas antioksidannya adalah Kulit jeruk dan daun sirih. Daun sirih yang sudah cukup dikenal masyarakat adalah sebagai obat tradisional dalam mengatasi beragam penyakit (Kurniawati et al., 2020). Daun sirih mengandung banyak komponen kimia seperti minyak atsiri, flavonoid, alkaloid, tanin, dan senyawa polifenolat (Serlahwaty et al., 20II). Komponen - komponen ini diketahui memiliki potensi kuat dalam anti-jamur, sifat anti-bakteri. Beberapa penelitian menyebutkan daun sirih sebagai antihistamin (Hazare et al., 20II) antifungi, antibacterial (Datta et al., 20II), antiproliferasi pada sel kanker payudara dan antioksidan (Pietta, 2000). Senyawa flavonoid paling banyak terkandung dalam jeruk nipis dibandingkan dengan spesies jeruk lainnya. Kulit jeruk nipis (citrus aurantifolia) telah diteliti mempunyai aktivitas antioksidan (Khasanah et al., 20l4). Senyawa yang berperan dalam antioksidan adalah flavonoid. Bagian dari jeruk nipis yang memiliki flavonoid paling besar adalah terletak pada kulit buahnya (Okwu, 2008).

Tanaman Bundung (Actinuscirpus Grossus) banyak ditemukan di Kalimantan dan secara empiris masyarakat menggunakannya sebagai antimikroba. Berdasarkan penelitian (Noval et al., 2019) tanaman bundung memiliki kandungan senyawa metabolit sekunder yaitu flavonoid, tannin, saponin, fenolik, steroid dan terpenoid. Tanaman bundung memiliki aktivitas antimikroba sehingga dapat dikembangkan menjadi produk antiseptik mulut (Noval et al., 2020). Antioksidan adalah senyawa yang dapat mereduksi radikal bebas sehingga dapat melindungi tubuh dari kerusakan akibat oksidasi yang berlebihan. Pengujian aktivitas antioksidan dapat menggunakan metode DPPH (2,2-diphenyl-I- picrilhidrazyl). Penangkapan radikal bebas DPPH dapat diamati dengan pengukuran absorbansi. Penurunan absorbansi adalah salah satu tanda reaksi penangkapan radikal bebas. Selain itu perubahan warna DPPH dari biru ke kuning adalah tanda adanya reduksi radikal oleh antioksidan atau reaksi antara senyawa radikal lainnya.

Tujuan penelitian ini untuk mengetahui seberapa besar kekuatan antioksidan dengan mengkombinasikan ketiga tanaman tersebut.

\section{METODOLOGI}

Bahan uji yang digunakan adalah Daun sirih (piper betle L), kulit jeruk nipis (citrus aurantifolia) dan tanaman bundung (actinuscirpus grossus). Alat dan bahan kimia yang digunakan DPPH (2,2-diphenyl-Ipicrilhidrazyl), quersetin, alat-alat gelas (Pyrex Iwakiß), sitroborat, metanol p.a (E. merck), asam asetat glasial (E.merck), aquadest, rotary evaporator (Heldolph®), blender simplisia (Miyako®), oven (Memmert UP400®), butanol (E. merck), etanol 96\% (E. merck), $\mathrm{FeCl} 3$ (E. merck), seperangkat alat maserasi, timbangan analitik (Precisa $®$ ).

Buah jeruk nipis (Citrus aurantifolia) diambil kulitnya dan tanaman bundung (Actinuscirpus Grossus) dikeringkan dengan cara dijemur secara tidak langsung selama 3 hari. Simplisia kering diblender sampai halus dan diayak sehingga diperoleh serbuk yang homogen. Masing-masing serbuk simplisia kulit jeruk nipis dan tanaman bundung ditimbang ditimbang $400 \mathrm{~g}$ dan 250g. Serbuk simplisisa kemudian diekstraksi dengan metode maserasi menggunakan pelarut etanol $96 \%$ dengan perbandingan I:I0. Hasil ekstraksi diambil lalu dipekatkan menggunakan rotary 
Kunti Nastati, Noval, Darini Kurniawati. 202I. Antioxidant Activity Combination Of Piper Betle Leaf Infusion, Ethanolic Extract Of Bundung (Actinuscirpus Grossus) And Citrus Fruit Peel Of Citrus Aurantifolia

evaporator $40 \mathrm{rpm}, 50^{\circ} \mathrm{C}$ sehingga diperoleh ekstrak kental kemudian ditimbang.

Daun sirih (Piper bitle L) segar 50g diekstraksi menggunakan metode infundasi dengan cara di stem didalam panci infusa selama 15 menit.

\section{Pengujian aktifitas antioksidan secara kualitatif}

Senyawa antioksidan diperiksa menggunakan Kromatografi Lapis Tipis (KLT) dengan fase gerak silika gel GF 254 dan fase gerak butanol : asam asetat : aquadest (4:I:5). Lempeng plat KLT kemudian ditotol dan dielusi. Selanjutnya lempeng tersebut disemprot menggunakan larutan DPPH. Setelah disemprot, didiamkan beberapa menit. Amati bercak yang muncul.

\section{Pengukuran daya antioksidan}

\section{Pembuatan larutan induk DPPH}

Larutkan DPPH yang akan digunakan dibuat dengan cara menimbang seksama lebih kurang $10 \mathrm{mg}$ DPPH ditimbang dan dilarutkan dengan methanol p.a dalam labu ukur 100,0 $\mathrm{ml}$ dan ditambahkan dengan methanol p.a hingga tanda batas, kocok sampai homogen sehingga didapatkan larutan DPPH 100 ppm. Larutan DPPH disimpan dalam wadah yang dilindungi dari cahaya dengan cara melapisi menggunakan aluminium foil dan disimpan pada suhu rendah untuk segera digunakan.

\section{Optimasi panjang gelombang maksimal}

Larutan DPPH 100 PPm ditentukan spectrum serapannya menggunakan spektrofotometer UV pada panjang gelombang $(\lambda) 200 \mathrm{~nm}$ hingga $800 \mathrm{~nm}$ serta ditentukan Lamda maksimumnya (Brand-Williams et al., 1995). Pengukuran selanjutnya dilakukan pada panjang gelombang maksimum tersebut.

\section{Operating time}

Penentuan larutan pembanding (kuersetin) dibuat 1000 Ppm dengan menimbang seksama $10 \mathrm{mg}$ kuersetin kemudian dilarutkan dalam metanol hingga volume 10 $\mathrm{mL}$. Dari larutan tersebut diambil I $\mathrm{mL}$ dan lalu ditambahkan metanol sampai tanda batas pada labu ukur $10 \mathrm{~mL}$, didapat larutan 100 ppm. Dari larutan 100 Ppm diambil 0,2 ml, selanjutnya dimasukkan ke dalam labu ukur $10 \mathrm{~mL}$ dan masing-masing ditambah metanol hingga tanda batas dan didapat konsentrasi 20 ppm. Diambil $2 \mathrm{ml}$ dari larutan tersebut, kemudian ditambah Iml larutan DPPH 100 ppm lalu ditambahkan dengan metanol Iml. Kemudian larutan didiamkan ditempat gelap selama 10 menit, 20 menit, 30 menit, 40 menit, 50 menit, 60 menit dicari menit dengan absorbansi konstan.

\section{Pembuatan larutan pembanding kuersetin}

Penentuan larutan pembanding (kuersetin) dibuat 1000 Ppm dengan menimbang seksama $10 \mathrm{mg}$ kuersetin kemudian dilarutkan dalam metanol hingga volume 10 $\mathrm{mL}$. Dari larutan tersebut diambil I $\mathrm{mL}$ dan lalu ditambahkan metanol sampai tanda batas pada labu ukur $10 \mathrm{~mL}$, didapat larutan 100 ppm. Dari larutan 100 ppm diambil masing-masing 0,2;0,3;0,4;0,5; dan 0,6 $\mathrm{mL}$ selanjutnya dimasukkan ke dalam labu ukur $10 \mathrm{~mL}$ dan masing-masing ditambah metanol hingga tanda batas dan didapat konsentrasi 30, 40, 50, dan 60 ppm. Diambil $2 \mathrm{ml}$ dari larutan tersebut, kemudian ditambah Iml larutan DPPH lalu ditambahkan dengan metanol I $\mathrm{ml}$. Kemudian larutan didiamkan ditempat gelap selama operating time yang ditentukan. Kemudian dibaca absorbansinya pada panjang gelombang maksimal yang telah ditentukan. ${ }^{4}$ Dilakukan replikasi sebanyak 3 kali.

\section{Pengukuran aktivitas antioksidan kombinasi} Infusa daun sirih, ekstrak kulit jeruk nipis dan ekstrak bundung

Pada penentuan larutan kombinasi (I:I:I) dibuat dengan cara menimbang seksama $5 \mathrm{mg}$ masing-masing ekstrak yang dilarutkan dalam metanol hingga volume $10 \mathrm{~mL}$ sebagai larutan induk kemudian dibuat bebagai seri konsentrasi yaitu 50, 100 dan 250 ppm selanjutnya dimasukkan ke dalam tabung reaksi sebanyak $2,0 \mathrm{ml}$, dalam tiap tabung reaksi ditambahkan I,0 mL larutan DPPH dalam I,0 ml metanol kemudian diinkubasi pada suhu ruang selama operating time. Larutan dibaca absorbansi pada spektrofotometer UV. ${ }^{4}$ Dilakukan replikasi sebanyak 3 kali.

\section{Analisis data}


Absorbansi dari kombinasi ekstrak yang diperoleh dibandingkan dengan absorbansi DPPH sehingga diperoleh \% aktivitas antioksidannya. Perhitungan persentase aktivitas antioksidan dapat menggunakan rumus :

$$
\% \text { Aktivitas Antioksidan }=\frac{A c-A}{A c} \times 100 \%
$$

Keterangan :

$A_{c}=$ Nilai absorbansi DPPH

$A=$ Nilai absorbansi sampel

Data hasil penentuan aktivitas antioksidan dengan metode DPPH dihitung nilai IC50 (Inhibitory Concentration) dengan menggunakan persamaan regresi linier. Nilai IC50 unttuk menentukan kategori kekuatan antioksidan.

\section{HASIL DAN PEMBAHASAN}

Antioksidan merupakan senyawa yang berfungsi untuk mencegah kerusakan oksidatif akibat radikal bebas yang masuk ke dalam tubuh. Pencegahan terhadap berbagai macam penyakit dapat diatasi dengan senyawa antioksidan ini. Penelitian ini menggunakan ketiga bahan alami yaitu daun sirih (Pipper betle), kulit jeruk nipis (Citrus aurantifolia) dan tanaman bundung (Actinuscirpus grossus).

\section{Pengujian senyawa kimia tumbuhan}

Pengujian dilakukan dengan kromatografi lapis tipis. Profil Kromatografi lapis tipis (KLT) digunakan untuk melihat pola kromatogram dari masing-masuing ekstrak pada penelitian. Mekanisme identifikasi dengan menggunakan KLT terjadi karena adanya pemisahan senyawa kimia pada sampel berdasarkan perbedaan kepolaran antara sampel dengan pelarut/eluen yang digunakan. Pelarut yang digunakan adalah campuran dari butanol : asam asetat : aquadest dengan perbandingan (4:1:5). Selanjutnya, plat KLT diamati di bawah sinar UV 254 dan 366 nm. Pada UV 254 nm lempeng KLT akan berflouresensi sedangkan sampel akan tampak berwarna gelap, sedangkan pada UV 366 $\mathrm{nm}$ noda yang akan berflouresensi dan lempeng tampak berwarna gelap. Pereaksi penyemprot yang digunakan dalam penelitian ini adalah adalah $\mathrm{FeCl}_{3}$, Sitroborat dam $\mathrm{H}_{2} \mathrm{SO}_{4}$.

Untuk mengidentifikasi senyawa polifenol digunakan pereaksi semprot $\mathrm{FeCl}_{3}$. Hasil elusi KLT disemprot menggunakan $\mathrm{FeCl}_{3}$, dimana senyawa golongan fenolik akan berubah menjadi berwarna biru. Hasil KLT dapat dilihat pada Gambar I.

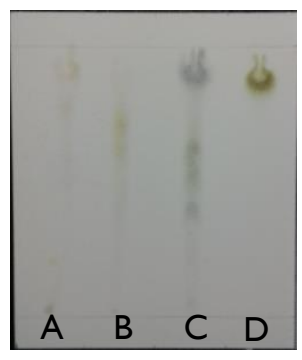

(I)

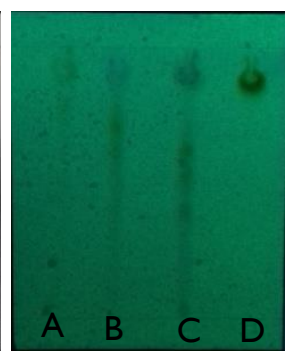

(II)

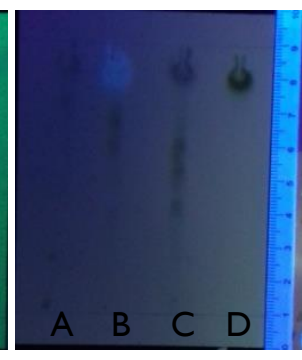

(III)
Gambar I. Hasil uji penyemprotan plat menggunakan pereaksi $\mathrm{FeCl}_{3}$ (I) pada sinar tampak (II) pada sinar UV254 (III) pada sinar UV366

Sedangkan untuk mengidentifikasi senyawa flavonoid digunakan pereaksi semprot sitroborat, terlihat pada Gambar 2. Pereaksi sitroborat menghasilkan warna kuning lebih jelas setelah disemprot menggunakan sitroborat. Hal ini menunjukkan adanya senyawa flavonoid.
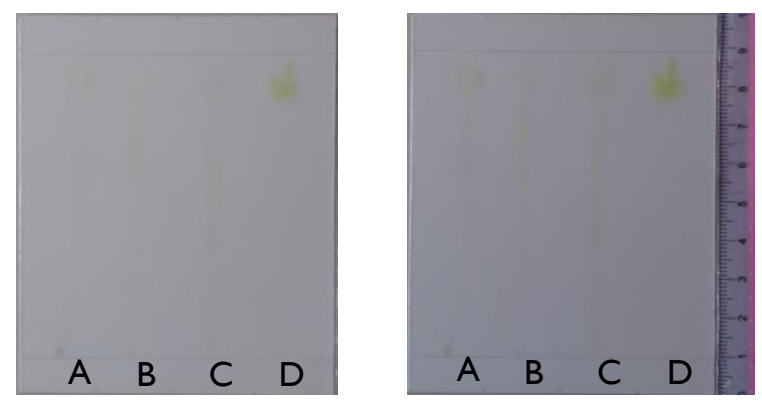

Gambar 2. Hasil uji penyemprotan KLT menggunakan pereaksi sitroborat pada sinar tampak.

Pengujian selanjutnya dengan menggunakan pereaksi $\mathrm{H}_{2} \mathrm{SO}_{4}$ menunjukkan adanya senyawa organik, dapat dilihat pada Gambar 3. Penyemprotan menggunakan $\mathrm{H}_{2} \mathrm{SO}_{4}$ menghasilkan spot yang lebih terlihat setelah dilakukan pemanasan pada plat KLT. Spot kehitaman 
Kunti Nastati, Noval, Darini Kurniawati. 202I. Antioxidant Activity Combination Of Piper Betle Leaf Infusion, Ethanolic Extract Of Bundung (Actinuscirpus Grossus) And Citrus Fruit Peel Of Citrus Aurantifolia

itu menunjukkan banyaknya senyawa-senyawa organik didalam tanaman.

$$
\text { A B } \quad \text { C } \quad \text { D }
$$

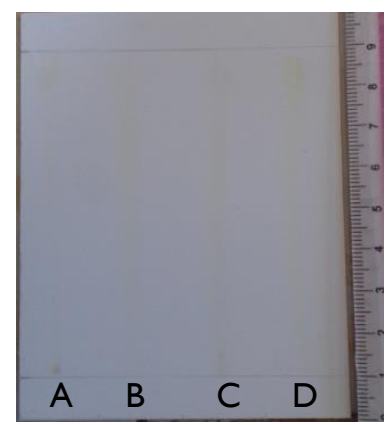

I

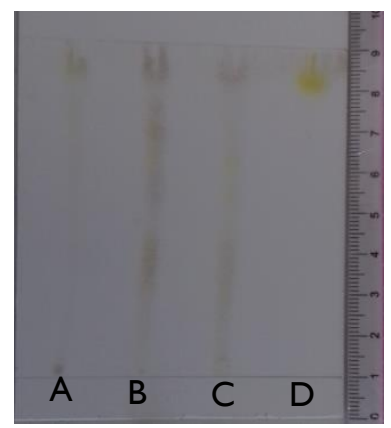

II

Gambar 3. Hasil uji setelah disemprot $\mathrm{H}_{2} \mathrm{SO}_{4} \quad 10 \%$ pada sinar tampak (I) sebelum disemprot (II) sesudah disemprot.

Keterangan gambar A (Ekstrak Bundung), B (Ekstrak Kulit jeruk nipis), C (Ekstrak Daun sirih), dan D (Quersetin).

\section{Pengujian antioksidan secara kualitatif}

Pengujian antioksidan secara kualitatif adalah dengan Kromatografi Lapis Tipis (KLT). Masing-masing ekstrak ditotolkan dan senyawa pembanding quersetin. Eluen yang digunakan butanol : asam asetat : aquades dengan perbandingan 4:1:5 yang biasa digunakan untuk identifikasi flavonoid. Menggunakan plat silika gel GF 254. Bercak akan memberikan perubahan warna kuning setelah disemprot dengan DPPH. Hal ini diartikan bahwa masing-masing ekstrak tersebut memiliki aktivitas antioksidan. Senyawa antioksidan pada masing-masing ekstrak tersebut akan bereaksi dengan radikal DPPH melalui mekanisme donasi atom nitrogen sehingga menyebabkan perubahan warna dari ungu ke kuning. Hasil uji kualitatif senyawa mempunyai aktivitas antioksidan ditunjukkan pada Gambar 4. Keterangan gambar A (Ekstrak Bundung), B (Ekstrak Kulit jeruk nipis), C (Ekstrak Daun sirih), dan D (Quersetin).

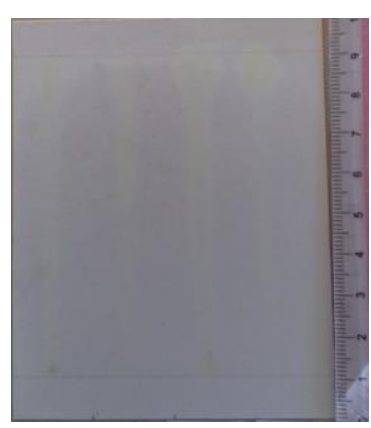

Gambar 4. Hasil Uji aktivitas antioksidan setelah disemprot DPPH pada sinar tampak.

\section{Pengujian antioksidan kuantitatif}

Berdasarkan hasil pengujian antioksidan kombinasi ekstrak, nilai rata-rata $I_{50}$ yang diperoleh untuk quersetin adalah sebesar 16,88 Ppm. Sedangkan kombinasi ekstrak mempunyai $I_{50} 128$ ppm. Hasil pengujian antioksidan untuk quersetin dan kombinasi ekstrak disajikan pada Tabel I dan II.

Tabel I. Hasil pengukuran aktivitas antioksidan quersetin dengan metode DPPH

\begin{tabular}{cccc}
\hline $\begin{array}{c}\text { Konsentrasi } \\
(\mathrm{Ppm})\end{array}$ & $\begin{array}{c}\text { \% Inhibisi } \\
(\%)\end{array}$ & $\begin{array}{c}\mathrm{IC}_{50} \\
(\mathrm{Ppm})\end{array}$ & $\begin{array}{c}\text { Kategori } \\
\text { antioksidan }\end{array}$ \\
\hline 30 & 62,8 & 16,88 & $<50$ ppm atau \\
40 & 68,4 & & sangat kuat \\
50 & 84,0 & & \\
60 & 88,3 & & \\
\hline
\end{tabular}

Tabel II. Hasil pengukuran aktivitas antioksidan sampel uji dengan metode DPPH

\begin{tabular}{lccl}
\hline $\begin{array}{c}\text { Konsentrasi } \\
(\mathrm{ppm})\end{array}$ & \% Inhibisi (\%) & $\begin{array}{c}\mathrm{IC}_{50} \\
(\mathrm{ppm})\end{array}$ & $\begin{array}{c}\text { Kategori } \\
\text { antioksidan }\end{array}$ \\
\hline 50 & 30,15 & 128 & $100-150$ \\
100 & 34,30 & & Ppm atau \\
250 & 90,68 & & sedang \\
\hline
\end{tabular}

Pengujian aktivitas antioksidan secara kuantitatif dilakukan dengan metode DPPH dengan merujuk pada prosedur Brand-Wiliams et al., 1995 dengan beberapa modofikasi. Pemilihan menggunakan metode DPPH ini dikarenakan merupakan metode yang sederhana, mudah diaplikasikan, cepat dan peka serta sampel yang digunakan hanya sedikit. Pengukuran aktivitas antioksidan secara kuantitatif menggunakan metode DPPH mempunyai prinsip adanya perubahan intensitas warna ungu DPPH yang sebanding dengan konsentrasi larutan DPPH tersebut. Elektron yang tidak 
berpasangan pada radikal bebas DPPH yang memberikan warna ungu. Perubahan warna ungu ke warna kuning saat elektron dari DPPH tersebut berpasangan. Perubahan ini terjadi karena adanya peredaman radikal bebas yang dihasilkan oleh bereaksinya molekul DPPH dengan atom hidrogen yang dilepaskan oleh molekul senyawa sampel, sehingga terbentuk senyawa difenil pikril hidrazin dan menyebabkan terjadinya perubahan warna DPPH dari ungu menjadi kuning. Perubahan warna ini mengakibatkan perubahan absorbansi pada panjang gelombang maksimum DPPH menggunakan spektrofotometer UV-Vis sehingga akan diketahui nilai aktivitas peredaman radikal bebas yang dinyatakan dengan nilai Inhibitory Concentration $\left(\mathrm{IC}_{50}\right)$.

Nilai $I_{50}$ didefinisikan sebagai besarnya konsentrasi senyawa uji yang dapat meredam radikal bebas sebanyak 50\%. Semakin kecil nilai $I_{50}$ maka aktivitas antioksidan semakin tinggi. Nilai $I_{50}$ diperoleh dari persamaan regresi linier yang menyatakan hubungan antara konsentrasi sampel uji sebagai sumbu $x$ dan $\%$ penangkapan radikal sebagai sumbu y. Suatu senyawa dikatakan sebagai antioksidan sangat kuat jika nilai $\mathrm{IC}_{50}$ kurang dari 50ppm, kuat (50-100ppm), sedang (100I50ppm), dan lemah (I5I-200ppm). Semakin kecil nilai semakin tinggi aktivitas antioksidan (Tristantini et al., 2016).

Pengujian aktivitas antioksidan secara kuantitatif pada kombinasi ekstrak yang berisi daun sirih, tanaman bundung dan kulit jeruk nipis serta untuk pembanding menggunakan quersetin dilakukan dengan berbagai seri konsentrasi menggunakan metode DPPH yang selanjutnya absorbansinya diukur dengan spektro UVVis.

Absorbansi sampel produk dengan DPPH diukur dengan menggunakan spektrofotometer UV-Vis terlebih dahulu ditentukan panjang gelombang maksimum dari DPPH. Panjang gelombang maksimum DPPH yang digunakan $517 \mathrm{~nm}$. Panjang gelombang maksimal ini memberikan serapan maksimal dari larutan uji dan kepekaan yang paling besar. Besarnya aktivitas antioksidan dari sampel produk dan kontrol pembanding yang digunakan diukur pada panjang gelombang maksimum.

Pembanding yang digunakan adalah quersetin yang diketahui memiliki aktivitas antioksidan karena memiliki gugus $-\mathrm{OH}$ fenolat dalam strukturnya yang bertanggung jawab terhadap aktivitas antioksidan karena mampu menjadi donor hidrogen atau elektron. Pengukuran aktivitas antioksidan sample uji dan larutan pembanding dengan metode DPPH dilakukan tiga kali replikasi. Hasil pengukuran menunjukkan bahwa semakin konsentrasi meningkat, nilai absorbansi yang dihasilkan akan semakin menurun. Hal ini dikarenakan, semakin besar konsentrasi larutan maka akan semakin banyak senyawa antioksidan yang menjadi donor hidrogen atu elektron pada DPPH sehingga terjadi perubahan warna DPPH. Warna Ungu dari DPPH akan berubah menjadi kuning seiring dengan meningkatnya konsentrasi dan menyebabkan absorbansi yang dihasilkan semakin kecil.

Nilai absorbansi yang didapat maka dapat dihitung persentase penghambatan radikal DPPH (\%inhibisi). Selanjutnya diperoleh kurva regresi linear dan persamaannya dengan konsentrasi sebagai sumbu $x$ dan absorbansi sebagai sumbu $y$. Nilai $I_{50}$ dapat dihitung dari persamaan regresi linear yang diperoleh dengan mengganti y dengan 50 pada persamaan tersebut. Semakin kecil nilai $I_{50}$ menunjukkan semakin tinggi aktivitas antioksidannya.

Berdasarkan hasil penelitian, senyawa yang memiliki potensi sebagai antioksidan pada ekstrak kulit jeruk, tanaman bundung dan daun sirih adalah flavonoid, alkaloid dan saponin. Flavonoid yang merupakan senyawa polifenol dapat berinteraksi dengan radikal bebas melalui reaksi netralisasi atau penghentian reaksi berantai yang terjadi. Senyawa alkaloid dapat bertindak sebagai peredam radikal bebas. Sedangkan saponin merupakan senyawa kimia tumbuhan yang dapat membentuk intermediet hidroperoksida dan mampu 
Kunti Nastati, Noval, Darini Kurniawati. 202I. Antioxidant Activity Combination Of Piper Betle Leaf Infusion, Ethanolic Extract Of Bundung (Actinuscirpus Grossus) And Citrus Fruit Peel Of Citrus Aurantifolia

meredam superoksida sehingga kerusakan biomolekuler akibat radikal bebas dapat dicegah (yuhernita, et al., 20II).

\section{KESIMPULAN}

Berdasarkan hasil penelitian dapat disimpulkan bahwa kombinasi ketiga ekstrak mempunyai aktivitas antioksidan kategori sedang dengan nilai $\mathrm{IC}_{50} 128$ ppm. Hasil penapisan kromatografi lapis tipis masing-masing ekstrak mengandung senyawa flavonoid, senyawa polifenol dan senyawa kimia lainnya.

\section{UCAPAN TERIMA KASIH}

Terimakasih yang sebesar-besarnya kami ucapkan kepada Rektorat Universitas Sari Mulia beserta jajarannya yang telah mendanai dan memberikan arahan terkait penelitian ini. Serta ucapan terima kasih kepada LPPM Universitas Sari Mulia yang banyak membantu dalam proses perizinan dan penelitian hingga kepada penyusunan akhir laporan ini.

\section{REFERENSI}

I. Pietta, P.-G. (2000). Flavonoids as Antioxidants. Journal of Natural Products, 63(7), 1035-1042. https://doi.org/10.1021/np9904509

2. Majewska, M., Skrzycki, M., Podsiad, M., \& Czeczot, H. (20II). Evaluation of antioxidant potential of flavonoids: an in vitro study. Acta Poloniae Pharmaceutica, 68(4), 61 I-615.

3. Haryono, I. A., Noval, N., \& Nugraha, B. (202I). Formulasi Buah Tampoi (Baccaurea macrocarpa) dalam Sediaan Masker Gel sebagai Antiaging. Jurnal Surya Medika (JSM), 6(2), 102-110. https://doi.org//0.33084/jsm.v6i2.2126

4. Noval, Noval, Melviani Melviani, Novia Novia, and Dahlia Syahrina. 2020. "Formulasi Dan Evaluasi Sediaan Obat Kumur (Mouthwash) Dari Ekstrak Etanol Tanaman Bundung (Actinoscirpus Grossus) Sebagai Antiseptik Mulut". Jurnal Surya Medika $\begin{array}{llll}\text { (JSM) } & 6 & \text { (I), } & \text { II2-20. }\end{array}$ https://doi.org//0.33084/jsm.v6il.1626.
5. Kurniawati, Darini, Noval Noval, and Kunti Nastiti. 2020. "POTENSI ANTISEPTIK POLIHERBAL DAUN SIRIH (Piper Betle), KULIT JERUK NIPIS (Citrus Aurantifolia) DAN TANAMAN BUNDUNG (Actinuscirpus Grossus) PADA TINDAKAN KEPERAWATAN DAN KEBIDANAN." Dinamika Kesehatan: Jurnal Kebidanan Dan Keperawatan II (I): 420-3I.

6. Noval, N., Nastiti, K., Nugraha, D., Rahmadani, R., \& Alawiyah, T. (2020). PRODUK INOVASI HAND SANITIZER DARI AKAR BAJAKAH SEBAGAI UPAYA PENCEGAHAN DI MASA PANDEMI COVID-19. LOGISTA - Jurnal Ilmiah Pengabdian Kepada Masyarakat, 4(2), 305-312. doi:10.25077/logista.4.2.305-3|2.2020.

7. Serlahwaty, D., Sugiastuti, S., \& Ningrum, R. C. (20II). Aktivitas Antioksidan Ekstrak Air dan Etanol 70\% Daun Sirih Hijau (Piper betle L.) dan Sirih Merah (Piper cf. fragile Benth.) dengan Metode Perendaman Radikal Bebas DPPH. Jurnal IImu Kefarmsian Indonesia, 9(2), I43-I46.

8. Hazare, R., Darvhekar, V., Shewale, A., \& Patil, V. (20II). Evaluation of antihistaminic activity of Piper betel leaf in guinea pig. In African Journal of Pharmacy and Pharmacology (Vol. 5).

9. Datta, A., Ghoshdastidar, S., \& Singh, M. (201I). Antimicrobial Property of Piper betel Leaf against Clinical Isolates of Bacteria. International Journal of Pharma Sciences and Research, 2(3), 104-109.

10. Okwu, D. E. (2008). Citrus fruits: A rich source of phytochemicals and their roles in human health. International Journal of Chemical Sciences, 6(2), 45I471 .

http://www.sadgurupublications.com/ContentPape r/2008/I_6(2)2008.pdf

II. Noval, N., Yuwindry, I., \& Syahrina, D. (2019). Phytochemical Screening and Antimicrobial Activity of Bundung Plants Extract by Dilution Method. Jurnal Surya Medika. https://doi.org// 0.33084/jsm.v5il.954.

12. Brand-Williams, W., Cuvelier, M. E., \& Berset, C. (1995). Use of a free radical method to evaluate antioxidant activity. LWT - Food Science and Technology, $\quad 28(\mathrm{I}), \quad 25-30$. 
https://doi.org/https://doi.org//0.1016/S00236438(95)80008-5

13. Tristantini, D., Ismawati, A., Pradana, B. T., \& Gabriel, J. (2016). Pengujian Aktivitas Antioksidan Menggunakan Metode DPPH pada Daun Tanjung ( Mimusops elengi L ). Universitas Indonesia, 2.

14. Ismiyyatun Khasanah, Ulfah, M., \& Sumantri, S. (20I4). UJI AKTIVITAS ANTIOKSIDAN EKSTRAK ETANOLIK KULIT BUAH JERUK NIPIS (Citrus aurantifolia) DENGAN METODE DPPH (I,I-difenil-2- pikrilhidrazil). E-Publikasi Fakultas Farmasi, II(2), 9-I7. https://publikasiilmiah.unwahas.ac.id/index.php/Far masi/article/view//363.

15. yuhernita, Juniarti. (20II). Analisis Senyawa Metabolit Sekunder Dari Ekstrak Metanol Daun Surian Yang Berpotensi Sebagai Antioksidan. MAKARA of Science Series, I5(I), 48-52. 